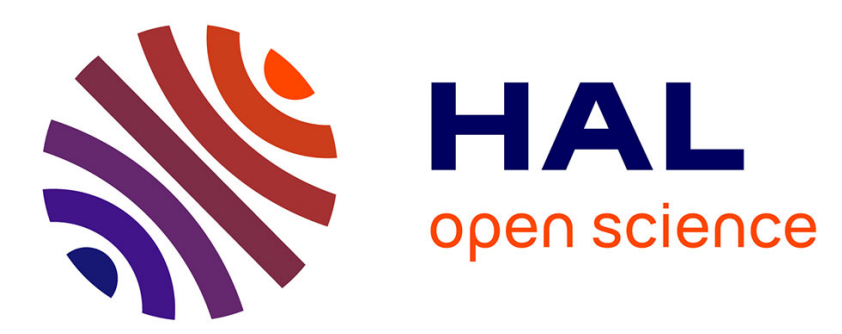

\title{
An Atom Probe Field Ion Microscope Study of Model Ni-Al Superalloys Containing Be
}

\author{
R. Thomson, K. Russell, M. Miller
}

\section{To cite this version:}

R. Thomson, K. Russell, M. Miller. An Atom Probe Field Ion Microscope Study of Model Ni-Al Superalloys Containing Be. Journal de Physique IV Proceedings, 1996, 06 (C5), pp.C5-259-C5-264. 10.1051/jp4:1996542 . jpa-00254421

\section{HAL Id: jpa-00254421 https://hal.science/jpa-00254421}

Submitted on 1 Jan 1996

HAL is a multi-disciplinary open access archive for the deposit and dissemination of scientific research documents, whether they are published or not. The documents may come from teaching and research institutions in France or abroad, or from public or private research centers.
L'archive ouverte pluridisciplinaire HAL, est destinée au dépôt et à la diffusion de documents scientifiques de niveau recherche, publiés ou non, émanant des établissements d'enseignement et de recherche français ou étrangers, des laboratoires publics ou privés. 


\title{
An Atom Probe Field Ion Microscope Study of Model Ni-Al Superalloys Containing Be
}

\author{
R.C. Thomson, K.F. Russell* and M.K. Miller* \\ Institute for Polymer Technology and Materials Engineering, Loughborough University, Loughborough, \\ Leicestershire, LE11 3TU, U.K. \\ * Metals and Ceramics Division, Oak Ridge National Laboratory, Oak Ridge, TN 37831-6376, U.S.A.
}

\begin{abstract}
Atom probe field ion microscopy and transmission electron microscopy have been used to characterise the phases present, and their compositions, in four model $\mathrm{Ni}-\mathrm{Al}$ superalloys containing $\mathrm{Be}$. In agreement with the limited information available on phase stability within the ternary $\mathrm{Ni}$-Al-Be system, atom probe results indicated that these alloys were in the three phase, $\gamma-\mathrm{Ni}, \gamma-\mathrm{Ni}_{3} \mathrm{Al}$ and $\beta-\mathrm{NiBe}$, region of the ternary diagram. Beryllium was found to substitute on the 'Al' sites within the $\gamma$, consistent with previous results from Be-doped NiAl. The experimental results have shown that the $\mathrm{Be}$ additions have resulted in the precipitation of phases enriched in $\mathrm{Be}$ within the $\gamma$ phase. The morphology of the phases enriched in Be ranged from monatomically thick plates to lenticular precipitates. Hardness measurements indicate significant hardening resulting from the addition of Be to model Ni-Al alloys.
\end{abstract}

\section{INTRODUCTION}

Nickel-based superalloys primarily consist of a face centred cubic $\mathrm{Ni}, \gamma$, matrix that contains a high density of $\mathrm{Ll}_{2}$-ordered $\mathrm{Ni}_{3} \mathrm{Al}$ precipitates, $\gamma^{\prime}$, with a small lattice mismatch between the two phases. At high temperatures the strength of the alloy depends primarily on the strength of the $\gamma$ phase [1]. The high temperature strength of these alloys begins to fall off above approximately $750^{\circ} \mathrm{C}$ and therefore this limits the maximum operating temperature of the alloy.

In this work, the possibility of strengthening the $\gamma$ phase by solid-state precipitation within the $\gamma$ has been investigated in model $\mathrm{Ni}$-Al superalloys containing Be. Beryllium is also expected to be a potent solid solution strengthener and has the additional advantage that it is a relatively light element.

The role of $\mathrm{Be}$ has been previously investigated in both $\mathrm{NiAl}$ [2] and $\mathrm{Ni}_{3} \mathrm{Al}$ [3]. In NiAl doped with 0.24 at.\% $\mathrm{Be}$, the $\mathrm{Be}$ was found to remain in solid solution in the matrix substituting on the $\mathrm{Al}$ sites. In $\mathrm{Ni}_{3} \mathrm{Al}$ doped with up to 5 at. $\% \mathrm{Be}$, significant improvements in both room temperature yield strength and ductility were observed. This study revealed that there was a rapid increase in the yield strength in the alloys containing up to 2 at.\% $\mathrm{Be}$ and there was a smaller increase in the higher Be alloys in which precipitates were observed.

The binary $\mathrm{Ni}-\mathrm{Al}$ phase diagram indicates that alloys containing $20 \% \mathrm{Al}$ consist of approximately $70 \% \gamma$ in a $\gamma$ matrix. In alloys containing up to $50 \% \mathrm{Be}$, the binary Ni-Be [4] system is a simple eutectic between $\gamma-\mathrm{Ni}$ and the $\mathrm{B} 2$-ordered $\mathrm{NiBe}, \beta$, phase, with the eutectic occurring at $1150^{\circ} \mathrm{C}$ and the solubility of $\mathrm{Be}$ in $\mathrm{Ni}$ at this temperature is approximately 15 at.\%. The mechanical properties of nickel beryllide, $\mathrm{NiBe}$, have been studied per se [5] because of interest in its good high temperature performance. It has been found to have some ductility at room temperature, and is readily deformable at high temperatures. Limited information is available on phase stability within the ternary Ni-Al-Be system [6]; however, alloys containing approximately 20 at.\% $\mathrm{Al}$ and up to 12 at.\% Be are likely to be in a three phase, $\gamma-\mathrm{Ni}, \gamma-$ $\mathrm{Ni}_{3} \mathrm{Al}$ and $\beta-\mathrm{NiBe}$, region of the ternary phase diagram. Movement of the liquidus projection with increasing levels of Be suggests that primary $\gamma$ will be found in the higher Be containing alloys, whereas only primary $\gamma$ will be found in the lowest Be containing alloy.

\section{EXPERIMENTAL DETAILS}

Four $\mathrm{Ni}-\mathrm{Al}-\mathrm{Be}$ alloys were manufactured from $\mathrm{Ni}-6 \mathrm{wt} . \% \mathrm{Be}$ and $\mathrm{Al}-15 \mathrm{wt} . \% \mathrm{Ni}$ master alloys by vacuum induction melting in a graphite crucible, the chamber being evacuated to $\sim 70 \mathrm{~Pa}$ and subsequently 
backfilled with argon. Liquid metal was poured into a $50 \times 50 \times 180 \mathrm{~mm}$ mold at a temperature of $1427^{\circ} \mathrm{C}$. The compositions of the alloys are given in Table 1 . The equilibrium phase diagram indicates that the volume fraction of $\mathrm{NiBe}$ will increase from $5 \%$ in alloy 1 to $25 \%$ in alloy 4 at the expense of the $\gamma$ phase, with the amount of $\gamma$ matrix remaining approximately constant.

Table 1: Measured chemical composition of the Ni-Al-Be alloys in both wt.\% and at.\%, with the balance being Ni. Low levels of carbon were present in all alloys, with all other elements being present only in trace quantities.

\begin{tabular}{|c|c|c|c|c|c|c|}
\hline Alloy & $\mathrm{Al} / \mathrm{wt} \%$ & $\mathrm{Be} / \mathrm{wt} \%$ & $\mathrm{C} / \mathrm{wt} . \%$ & $\mathrm{Al} /$ at.\% & $\mathrm{Be} /$ at.\% & $\mathrm{C} / \mathrm{at} . \%$ \\
\hline 1 & 9.8 & 0.27 & 0.016 & 18.8 & 1.56 & 0.069 \\
\hline 2 & 10.0 & 0.46 & 0.018 & 19.0 & 2.62 & 0.077 \\
\hline 3 & 9.6 & 0.97 & 0.030 & 17.9 & 5.40 & 0.126 \\
\hline 4 & 9.0 & 2.25 & 0.024 & 15.9 & 11.90 & 0.095 \\
\hline
\end{tabular}

Specimens of size $10 \times 10 \times 40 \mathrm{~mm}$ cut from the ingots were sealed in silica tubes under a partial pressure of $\operatorname{argon}\left(2 \times 10^{4} \mathrm{~Pa}\right)$ and were homogenized at $1100^{\circ} \mathrm{C}$ for $8 \mathrm{~h}$. The samples were then water quenched and sealed in silica tubes a second time prior to heat treatments at 500 and $800^{\circ} \mathrm{C}$ for $1 \mathrm{~h}$ respectively. The specimens were subsequently water quenched.

Samples for optical microscopy were etched using Kalling's reagent ( $5 \mathrm{~g}$ of copper chloride in 100 $\mathrm{ml}$ hydrochloric acid and $100 \mathrm{ml}$ methanol). Thin foil specimens for examination in a JEOL $100 \mathrm{kV}$ transmission electron microscope (TEM) were prepared by punching $3 \mathrm{~mm}$ discs from wafers cut from the larger bars, mechanically grinding by hand to a thickness of $50 \mu \mathrm{m}$ and twin-jet electropolishing to electron transparency at $20 \mathrm{~V}$, with the solution being cooled to $-15^{\circ} \mathrm{C}$ with liquid nitrogen. The polishing solution used was a mixture of $10 \%$ perchloric acid, $20 \%$ glycerol and $70 \%$ ethanol. After electropolishing, foils of two of the alloys were additionally ion-beam thinned using a current of $5 \mu \mathrm{A}$ at $7 \mathrm{kV}$ for $0.5 \mathrm{~h}$ to overcome problems with preferential polishing.

Blanks were cut from the heat treated specimens of size $0.5 \times 0.5 \times 20 \mathrm{~mm}$. Needles for examination in the atom probe were then prepared using a two stage electropolishing technique. Specimens were resharpened by back-polishing. Atom probe analyses were performed using the Oak Ridge National Laboratory's energy-compensated atom probe [7,8]. Analyses were performed at $50 \mathrm{~K}$ and a voltage pulse fraction of $20 \%$. Since the mass-to-charge ratio for both $\mathrm{Be}^{+}$and $\mathrm{Al}^{3+}$ ions is $9 \mathrm{u}$, peak overlap occurs. Careful examination of data for $\mathrm{Fe}-25$ at. $\% \mathrm{Be}$ [9] and $\mathrm{Ni}_{3} \mathrm{Al}$ alloys taken under comparable experimental conditions showed that there was only $0.1 \%$ of $\mathrm{Be}^{+}$and $0.5-1 \%$ of $\mathrm{Al}^{3+}$ ions. Therefore, the peak at a mass-to-charge ratio of $9 \mathrm{u}$ was assigned to the more common $\mathrm{Al}^{3+}$ ions.

\section{RESULTS AND DISCUSSION}

Optical micrographs for alloys 1 and 4 heat treated at $1100^{\circ} \mathrm{C} 8 \mathrm{~h}+500^{\circ} \mathrm{C} 1 \mathrm{~h}$ are presented in Fig. 1 . The difference in $\gamma$ morphology is clearly visible. Alloy 1 has the appearance of a 'conventional' Ni-based superalloy, showing cuboidal $\gamma$ precipitates in a $\gamma$ matrix, whereas alloy 4 shows primary $\gamma$ with a $\gamma / \gamma$ eutectic intergrowth in between the $\gamma^{\prime}$ plates.

Vickers hardness measurements are presented in Table 2. A significant hardening effect resulting from the addition of $\mathrm{Be}$ is evident. The effect is more noticeable after the higher $800^{\circ} \mathrm{C}$ heat treatment and is a consequence of enhanced reaction kinetics at the higher temperature.

Table 2: Vickers hardness measurements using a $30 \mathrm{~kg}$ load. Data are the mean of 3 measurements per sample, with an error of $\pm 3 \mathrm{HV}$.

\begin{tabular}{|c|c|c|c|}
\hline Alloy & $1100^{\circ} \mathrm{C} 8 \mathrm{~h} / \mathrm{HV}$ & $1100^{\circ} \mathrm{C} 8 \mathrm{~h}+500^{\circ} \mathrm{C} 1 \mathrm{~h} / \mathrm{HV}$ & $1100^{\circ} \mathrm{C} 8 \mathrm{~h}+800^{\circ} \mathrm{C} 1 \mathrm{~h} / \mathrm{HV}$ \\
\hline 1 & 234 & 215 & 232 \\
\hline 2 & 236 & 254 & 302 \\
\hline 3 & 314 & 327 & 358 \\
\hline 4 & 399 & 415 & 433 \\
\hline
\end{tabular}


Atom probe analyses showed that the Be in solid solution was almost exclusively found on $\mathrm{Al}$ sites within the $\gamma$ precipitates. This is illustrated in Fig. 2 in which the composition of successive $\{100\}$ planes is plotted for alloy 3 after heat treatment at $1100^{\circ} \mathrm{C} 8 \mathrm{~h}+800^{\circ} \mathrm{C} 1 \mathrm{~h}$. The level of Be in solid solution in $\gamma$ was found to be $1.8 \pm 0.1$ at. \%, consistent with the solubility of $\mathrm{Be}$ in $\gamma$.

(a)

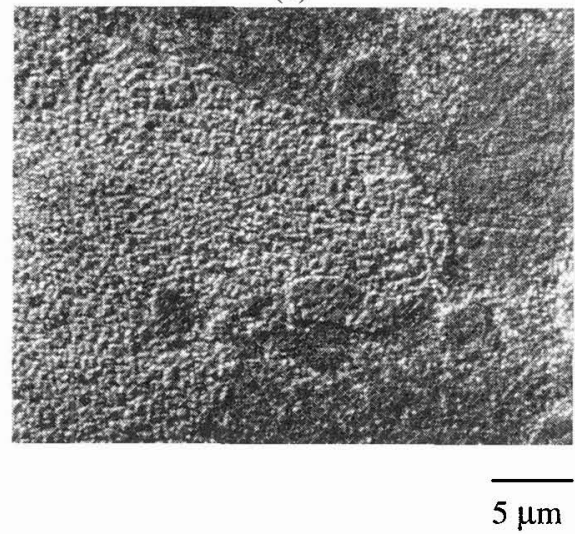

(b)

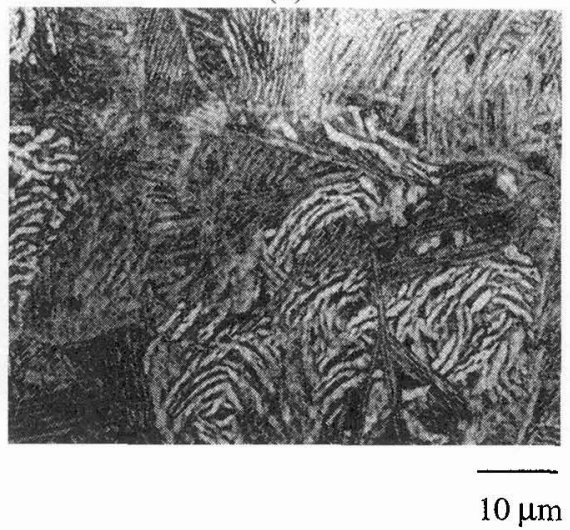

Figure 1: Optical micrographs of alloy 1 (a) and alloy 4 (b) showing the difference in $\gamma$ morphology.

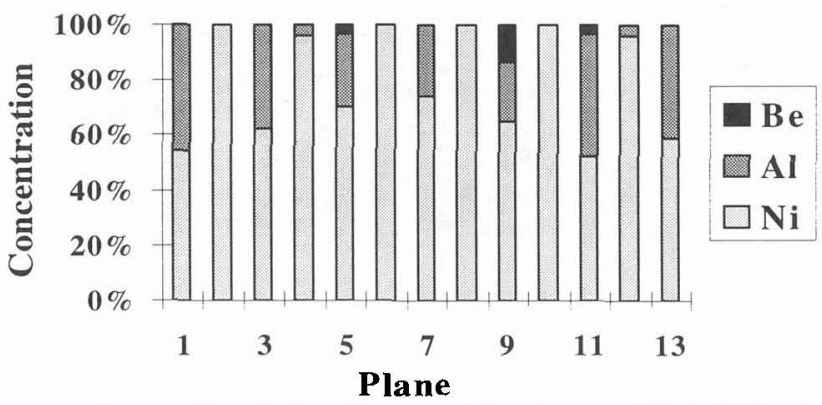

Figure 2: An atom probe composition profile of alternating pure $\mathrm{Ni}$ and mixed $\mathrm{Ni} / \mathrm{Al}$ (100) planes. Be was found almost exclusively on Al sites. Analyses were performed at $9 \mathrm{kV}$ with approximately 26 ions per plane.

Atom probe analyses of alloy 1 heat treated at both 800 and $500^{\circ} \mathrm{C}$ showed the microstructure to consist primarily of the $\gamma$ and $\gamma$ phases. Typical compositions of the $\gamma$ and $\gamma$ phases were $86.9 \pm 0.5$ at. $\%$ $\mathrm{Ni}-11.7 \pm 0.5 \% \mathrm{Al}-1.4 \pm 0.2 \% \mathrm{Be}$ and $76.5 \pm 0.4 \% \mathrm{Ni}-22.7 \pm 0.4 \% \mathrm{Al}-0.8 \pm 0.1 \% \mathrm{Be}$, respectively. The Be partitioned into the $\gamma$ matrix. These data represent the mean of several analyses totalling over 100,000 ions.

Atom probe analyses from alloy 2 tempered at $500^{\circ} \mathrm{C}$ for $1 \mathrm{~h}$ indicated a very similar microstructure to that of alloy 1 , with the composition of the $\gamma^{\prime}$ increasing in Be to $76.0 \pm 0.5$ at.\% $\mathrm{Ni}$ $22.2 \pm 0.5 \% \mathrm{Al}-1.8 \pm 0.3 \% \mathrm{Be}$ as expected due to the increased $\mathrm{Be}$ in the bulk alloy. However, specimens of alloys 2 and 3 tempered at $800^{\circ} \mathrm{C}$ for $1 \mathrm{~h}$ were found to contain large numbers of ultrathin brightly-imaging regions within the $\gamma$ phase, as illustrated in Fig. 3. The same features, although thinner and lower in number density, were also found in alloy 3 tempered at $500^{\circ} \mathrm{C}$ for $1 \mathrm{~h}$. Similar brightly imaging regions have previously been observed in the $\gamma$ matrix of a binary $\mathrm{Ni}-12$ at.\% Be alloy [10]. No segregation of Be to $\gamma / \gamma$ boundaries was observed.

Bright field and dark field transmission electron micrographs and the corresponding selected area electron diffraction pattern from a specimen of alloy 2 tempered at $800^{\circ} \mathrm{C}$ for $1 \mathrm{~h}$ are presented in Fig. 4 . The diffraction pattern, with a [100] zone axis, shows streaking parallel to the 200 planes. The dark field 
micrograph is taken with the aperture over one of the streaks, indicating that it is indeed associated with the linear features which are giving rise to the contrast. Using two beam conditions in the electron microscope, one orientation of linear features are visible with $\mathbf{g}=002$ beam, the other with $\mathbf{g}=2 \overline{2} 0$ and both orientations with $\mathbf{g}=1 \overline{1} 1$ beam indicating that the features are on $\{100\}$ planes in the $\gamma$ phase.

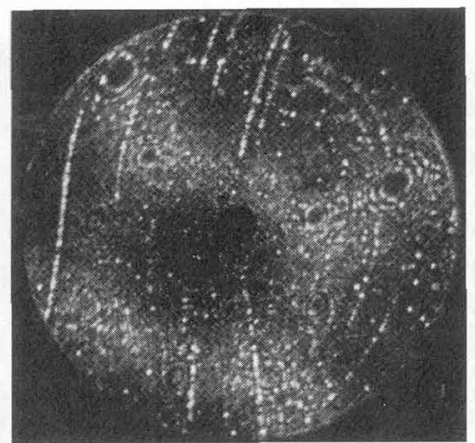

Figure 3: A neon field ion micrograph showing very thin brightly imaging regions within the $\gamma$ phase in alloy 3 heat treated at $1100^{\circ} \mathrm{C} 8 \mathrm{~h}+800^{\circ} \mathrm{C} 1 \mathrm{~h}$.
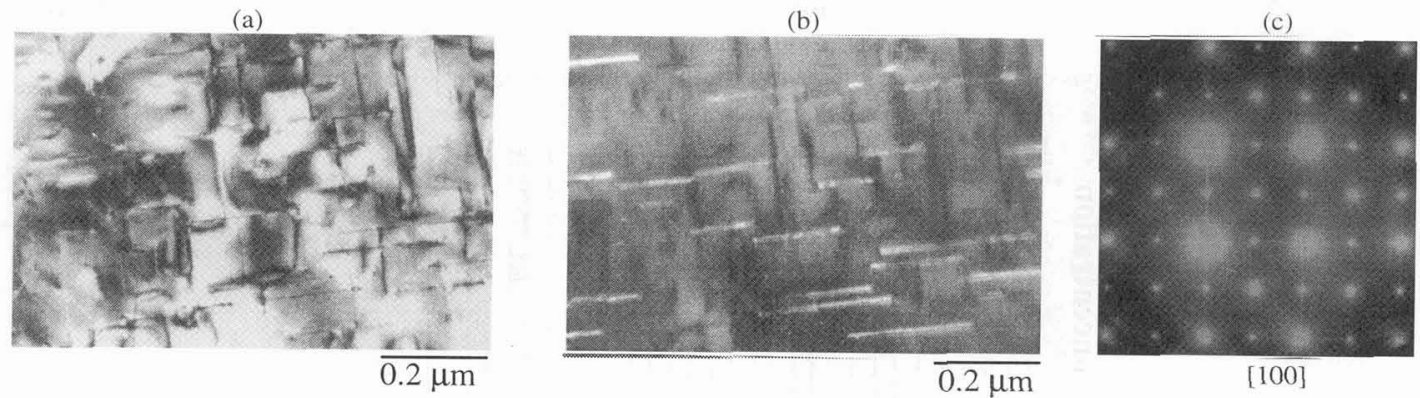

Figure 4: Bright (a) and dark (b) field transmission electron micrographs showing linear features giving rise to the streaks in the $[100] \gamma$ diffraction pattern (c).

The brightly-imaging plates in the field ion images were generally found to be coherent with the $\gamma$ matrix as shown in Fig. 5(a). In this micrograph, a single brightly-imaging (100) atomic terrace is evident in $\gamma$ phase. There is no disruption of the surrounding ordered $\mathrm{Ni}$ and mixed $\mathrm{Ni} / \mathrm{Al}$ planes. Accurate composition determination of the thin brightly-imaging platelets was difficult because of their size relative to the probe aperture [11], however all traverses across such features showed them to be enriched in $\mathrm{Be}$, with concentrations ranging from $10-35$ at.\% Be with virtually no $\mathrm{Al}$.

(a)

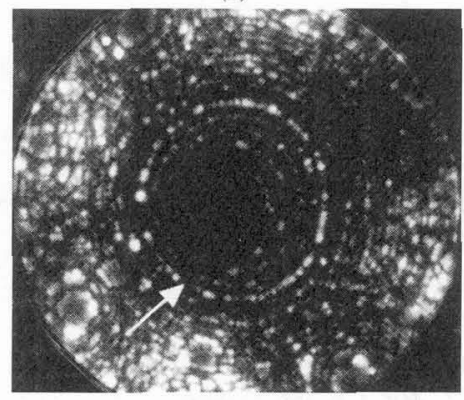

(b)

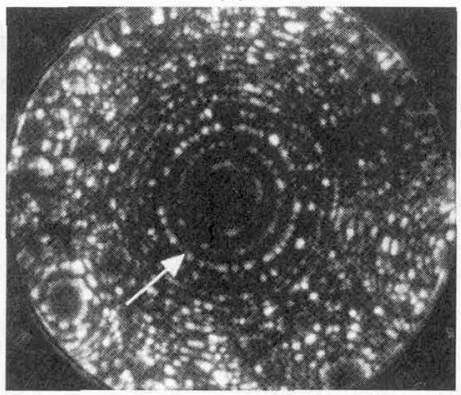

(c)

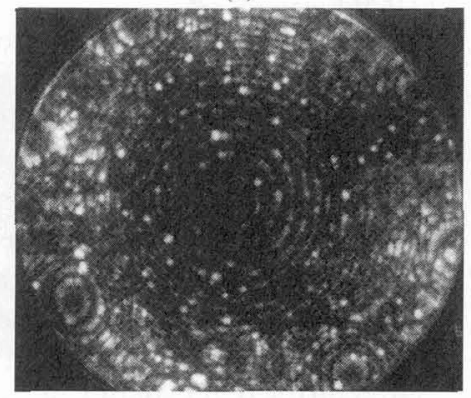

Figure 5: Neon field ion micrographs showing the evaporation sequence of a brightly imaging precipitate intersecting a $<100>$ $\gamma$ pole in alloy 2 heat treated at $1100^{\circ} \mathrm{C} 8 \mathrm{~h}+800^{\circ} \mathrm{C} 1 \mathrm{~h}$. 
Much more extensive precipitation was observed in alloy 4 tempered at both 500 and $800^{\circ} \mathrm{C}$. In addition to the ultrathin features enriched in Be seen in the lower Be alloys, much thicker, lenticular, precipitates were observed in alloy 4, as shown in Fig. 6. The composition of these precipitates could be accurately determined by careful selection of the effective size of the probe aperture [11] and was found to be $\mathrm{Ni}-47.8 \pm 0.6$ at. $\% \mathrm{Be}, 0.05 \pm 0.03 \% \mathrm{Al}$. Virtually no $\mathrm{Al}$ was found in the precipitates indicating that the precipitate is the $\mathrm{NiBe}$ phase. Selected area electron diffraction confirmed that the larger precipitates in alloy 4 were $\mathrm{NiBe}$, with a $\mathrm{B} 2$-ordered structure, Fig. 7. It was noted that such precipitates did not have as striking an orientation relationship with the $\gamma$ matrix as the thinner phase enriched in $\mathrm{Be}$ it is likely that the thicker NiBe precipitates are inclined at an angle of a few degrees to $\{100\}_{\gamma}$. The phase enriched in $\mathrm{Be}$, which is only a few atomic layers thick and has a composition close to $\mathrm{Ni}_{3} \mathrm{Be}$, is completely coherent with the $\gamma$, analogous to G.P. zones. With increasing Be concentrations and time at temperature, thicker $\mathrm{NiBe}$ precipitates are able to form. The lattice parameter of $\mathrm{NiBe}$ is $2.61 \AA$ [12], compared with $3.56 \AA$ for the $\gamma$ phase. Therefore, lattice matching is possible with $\langle 100\rangle \gamma \|<110\rangle$ $\mathrm{NiBe}$.
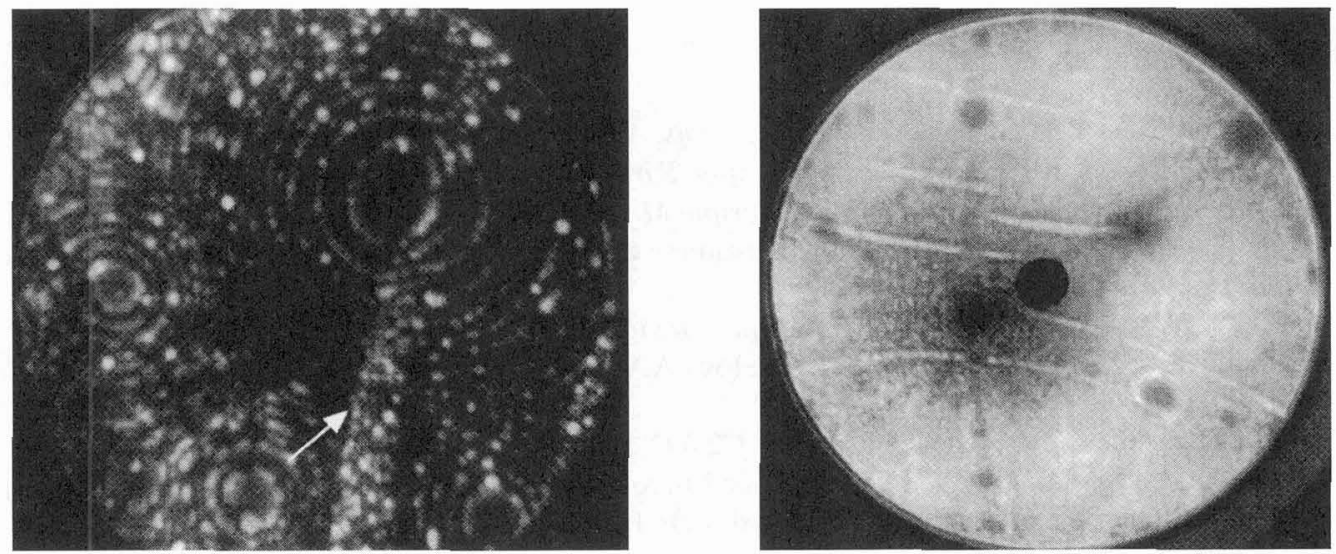

Figure 6: Neon field ion micrographs showing brightly imaging precipitates in $\gamma$ in alloy 4 heat treated at $1100^{\circ} \mathrm{C} 8 \mathrm{~h}+800^{\circ} \mathrm{C}$ $1 \mathrm{~h}$.

(a)

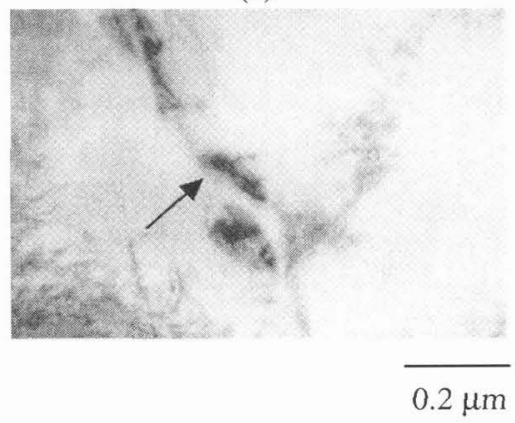

(b)

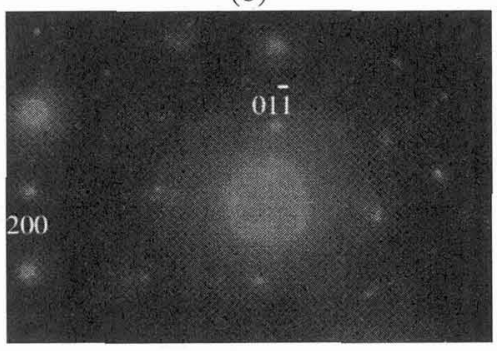

[011]

Figure 7: Bright field transmission electron micrograph (a) showing an NiBe precipitate within the $\gamma$ matrix and the corresponding electron diffraction pattern (b) showing it possesses the B2 crystal structure. 


\section{CONCLUSIONS}

Beryllium additions were found to increase the hardness of the $\gamma$ phase as a result of both precipitation and solid solution strengthening. The morphology of phases enriched in Be ranged from monatomically thick plates to lenticular precipitates. The effect of prolonged ageing on the precipitation kinetics of phases enriched in $\mathrm{Be}$ within the microstructure is the subject of ongoing investigations.

\section{Acknowledgements}

This research was sponsored by the Division of Materials Sciences, U.S. Department of Energy, under contract DE-AC05-96OR22464 with Lockheed Martin Energy Research Corp., and the Royal Society, U.K. Some of this research was conducted utilizing the Shared Research Equipment (SHaRE) user program facilities at Oak Ridge National Laboratory. The authors would like to thank Dr A. Guha of Brush Wellman Inc. for supplying the alloys, Dr H. Bhadeshia for fruitful discussions and $\mathrm{Mr} J$. Bates for his technical assistance.

\section{References}

[1] Piercey B.J., Kear B.H. and Smashey R.W., Trans. Am. Soc. Met., 60 (1967) 634-645.

[2] Jayaram R., Russell K.F. and Miller M.K., Appl. Surf. Sci., 67 (1993) 316-320.

[3] Takasugi T., Masahashi N. and Izumi O., Scripta Metall., 20 (1986) 1317-1321.

[4] 'Phase diagrams of binary Be alloys', H. Okamoto and L.E. Tanner Eds. (ASM International, Metals Park, $\mathrm{OH}, 1987$ ).

[5] Nieh T.G., Wadsworth J.and Liu C.T., Scripta Metall., 22 (1988) 1409-1413.

[6] Molchanova L.V., Naimushin S.G., Novoselova A.V. and Savikova L.A., Vestn. Mosk. Univ., Khim., 27(3) (1986) 266-271.

[7] Miller M.K., J. de Phys. (Paris), 47 (1986) C2 493-504.

[8] Miller M.K. and Smith G.D.W., 'Atom Probe Microanalysis: Principles and Applications to Materials Problems', Materials Research Society, Pittsburgh, PA (1989).

[9] Miller M.K. and Burke M.G., unpublished.

[10] Liu Z.G., Al-Kassab T. and Haasen P., Surface Science, 246 (1991) 329-335.

[11] Miller M.K. and Thomson R.C., J. de Physique, this conference.

[12] Frederich K.M., Jönsson S., Aldinger, F. and Petzow G., Z. Metallkunde, 71 (1980) 584-587. 